\title{
Comparison of Strength of Isoagglutinin Titres in English and Finnish Populations
}

\author{
I. J. T. SEPPÄLÄ \\ From the Department of Serology and Bacteriology, University of Helsinki, Finland
}

To some extent the strength of the anti-A and anti-B isoagglutinins seems to be genetically determined, though modified by environmental factors (Renkonen, 1946; Carlinfanti, 1948). The strength of the isoagglutinins in Germans and Finns has been compared earlier. The Finnish titres were higher, and the $\mathrm{A}$ and $\mathrm{B}$ gene frequencies were higher in Finland than in Germany (Savolainen, 1946). The purpose of the present work is to discover whether an analogous correlation exists between the isoagglutinin titres and the $A$ and $B$ gene frequencies in England and Finland.

This kind of study is difficult because external factors are known to influence isoagglutinin titres. A seasonal variation in the titres has been observed (Stone and Shaw, 1957). This might influence the statistical distribution of children with different blood groups born during the course of the year (Gerschowitz, 1967). The isoagglutinin titre is also affected by contact with microbial antigens (Springer, Horton, and Forbes, 1959), the altitude at which the subject lives (Ruffié et al., 1967), and his age (Thomsen and Kettel, 1929).

\section{Material and Methods}

In this study the blood donors examined were all blood group O, male, and between 19 and 25 years old. The samples were collected at the same time in both countries and kept frozen until titration. The English samples were sent to Finland by air in vacuum flask containers in a frozen state. The samples from the two countries were mixed and titrated blind. Each sample was titrated twice in doubling dilutions from $1 / 2$ to 1/256. $A_{1}$ and $B$ erythrocytes from the same persons were used throughout the experiment.

\section{Results}

The results have been calculated, both according to the last positive tube and from the total agglutination count for each sample (scoring the agglu-

Received July 29, 1968. tination from 0 to 4). Regardless of how the end point was recorded, a significant difference between English and Finnish samples was observed for the anti-B titres but not for the anti-A titres (Tables I and II). This result is in accordance with the hypo-

TABLE I

END POINT TITRATION

\begin{tabular}{|c|c|c|c|c|c|c|c|c|}
\hline & \multicolumn{2}{|c|}{ Anti-A I } & \multicolumn{2}{|c|}{ Anti-A II } & \multicolumn{2}{|c|}{ Anti-B I } & \multicolumn{2}{|c|}{ Anti-B II } \\
\hline & $\begin{array}{l}\text { Fin- } \\
\text { land }\end{array}$ & $\begin{array}{l}\text { Eng- } \\
\text { land }\end{array}$ & $\begin{array}{l}\text { Fin- } \\
\text { land }\end{array}$ & $\begin{array}{l}\text { Eng- } \\
\text { land }\end{array}$ & $\begin{array}{l}\text { Fin- } \\
\text { land }\end{array}$ & $\begin{array}{l}\text { Eng- } \\
\text { land }\end{array}$ & $\begin{array}{l}\text { Fin- } \\
\text { land }\end{array}$ & $\begin{array}{l}\text { Eng- } \\
\text { land }\end{array}$ \\
\hline $\begin{array}{l}\overline{\mathbf{x}} \\
\mathbf{s} \\
\mathbf{N}\end{array}$ & $\begin{array}{c}6.07 \\
1.23 \\
99\end{array}$ & $\begin{array}{l}5.98 \\
1.26 \\
100\end{array}$ & $\begin{array}{c}5.95 \\
1.08 \\
97\end{array}$ & $\begin{array}{l}5 \cdot 73 \\
1.11 \\
100\end{array}$ & $\begin{array}{l}5 \cdot 17 \\
1.38 \\
100\end{array}$ & $\begin{array}{c}4.55 \\
1.22 \\
99\end{array}$ & $\begin{array}{c}5 \cdot 84 \\
1 \cdot 24 \\
99\end{array}$ & $\begin{array}{c}5.07 \\
1.45 \\
99\end{array}$ \\
\hline$p(t)$ & \multicolumn{2}{|c|}{ NS } & \multicolumn{2}{|c|}{ NS } & \multicolumn{2}{|c|}{$<0.001$} & \multicolumn{2}{|c|}{$<0.001$} \\
\hline
\end{tabular}

Table I has been calculated according to the last positive tube, $\overline{\mathbf{x}}$ is the mean of the positive tubes in the titration.

$\overline{\mathbf{x}}=$ mean, $\mathbf{s}=$ standard deviation, $\mathbf{N}=$ number of subjects, $\mathrm{NS}=$ not significant $(p(t)>\cdot 05)$.

TABLE II

TOTAL AGGLUTINATION COUNT

\begin{tabular}{|c|c|c|c|c|c|c|c|c|}
\hline & \multicolumn{2}{|c|}{ Anti-A I } & \multicolumn{2}{|c|}{ Anti-A II } & \multicolumn{2}{|c|}{ Anti-B I } & \multicolumn{2}{|c|}{ Anti-B II } \\
\hline & $\begin{array}{l}\text { Fin- } \\
\text { land }\end{array}$ & $\begin{array}{l}\text { Eng- } \\
\text { land }\end{array}$ & $\begin{array}{l}\text { Fin- } \\
\text { land }\end{array}$ & $\begin{array}{l}\text { Eng- } \\
\text { land }\end{array}$ & $\begin{array}{l}\text { Fin- } \\
\text { land }\end{array}$ & $\begin{array}{l}\text { Eng- } \\
\text { land }\end{array}$ & $\begin{array}{l}\text { Fin- } \\
\text { land }\end{array}$ & $\begin{array}{l}\text { Eng- } \\
\text { land }\end{array}$ \\
\hline $\begin{array}{l}\overline{\mathbf{x}} \\
\mathbf{s} \\
\mathbf{N}\end{array}$ & $\begin{array}{r}17.9 \\
5.0 \\
99 \\
\end{array}$ & $\begin{array}{r}17.6 \\
4.9 \\
100 \\
\end{array}$ & $\begin{array}{c}17 \cdot 9 \\
4.4 \\
97\end{array}$ & $\begin{array}{r}16.9 \\
4.5 \\
100\end{array}$ & $\begin{array}{r}14 \cdot 7 \\
5 \cdot 0 \\
100\end{array}$ & $\begin{array}{c}12 \cdot 3 \\
4 \cdot 6 \\
99\end{array}$ & $\begin{array}{c}16.9 \\
4.9 \\
99\end{array}$ & $\begin{array}{c}14 \cdot 0 \\
4 \cdot 4 \\
99\end{array}$ \\
\hline$p(t)$ & \multicolumn{2}{|c|}{ NS } & \multicolumn{2}{|c|}{ NS } & \multicolumn{2}{|c|}{$<0.001$} & \multicolumn{2}{|c|}{$<0.001$} \\
\hline
\end{tabular}

Table II has been calculated according to the total agglutination count for each sample. $\overline{\mathbf{x}}$ is the mean of the score.

thesis (Renkonen, Seppälä, and Timonen, 1968) that there is a connexion between the high frequency of the B gene and the high anti-B titres in Finland. However, South American Indians, who have extremely low A and B gene frequencies, have very high isoagglutinin titres (Ruffié et al., 1967).

\section{Summary}

The isoagglutinin titres in English and Finnish blood group $\mathrm{O}$ persons were compared. The 
anti-B titres were found to be significantly lower in the English population than in the Finnish samples. The anti-A titres were on the same level.

I wish to express my gratitude to $\mathrm{Dr}$. K. O. Renkonen for much advice, and to Drs. Wagstaff, Sheffield Blood Transfusion Service, R. A. Zeitlin, South London Transfusion Centre, H. R. Nevanlinna, the Finnish Red Cross Blood Transfusion Centre, and E. Ruoslahti, State Serum Institute, Finland, for making the samples available.

\section{Addendum}

The isoagglutinin titres of $\mathbf{2 5}$ group $\mathrm{O}$ sera from Peruvian Cashinahua Indians, kindly supplied by Dr. B. Blumberg, did not differ from titres in Finnish sera.

\section{REFERENCES}

Carlinfanti, E. (1948). The predisposition for immunity. $f$.() Immunol., 59, 1.

Gerschowitz, H. (1967). A possible relationship between birth " month and ABO blood type. Amer. F. hum. Genet., 19, 450.

Renkonen, K. O. (1946). Sind die Isoagglutinintiter erblich bedingt? Acta path. microbiol. scand., 23, 549.

- Seppälä, M., and Timonen, S. (1968). Further factors influencing Rh-immunization: II. f. med. Genet., 5, 123.

Ruffié, J., Ducos, J., Larrouy, G., Marty, Y., and Ohayon, E. (1967) Sur la fréquence élevée des anticorps anti-A et anti-B de haut titre $\overparen{D}$ dans les tribus amérindiennes. Rôle possible comme facteur sélectif. C.R. Acad. Sci. (Paris), (Série D), 264, 1792

Savolainen, T. (1946). Gibt es Unterschiede zwischen den Isoagglutinintitern der einzelnen Völker? Acta path. microbiol. $\overrightarrow{0}$ scand., 23, 552.

Springer, G. F., Horton, R. E., and Forbes, M. (1959). Origin of $\overrightarrow{\vec{A}}$ anti-human blood group $B$ agglutinins in white leghorn chicks. F. exp. Med., 110, 221.

Stone, W. H., and Shaw, D. H. (1957). Seasonal variation of naturally occurring iso-antibodies of man. Commun. 6th europ. Haemat. Cong. Copenhagen.

Thomsen, O., and Kettel, K. (1929). Die Stärke der menschlichen N Isoagglutinine und entsprechenden Blutkörperchenrezeptoren in $\vec{G}$ verschiedenen Lebensaltern. $\quad Z$. Immun.-Forsch., 63, 67. 